\title{
Tata Kelola Pemerintahan dalam Hukum Islam
}

\author{
Nur Paikah ${ }^{1}$ \\ Fakultas Syariah dan Hukum Islam, Jl. Hos Cokroaminoto \\ Email: 1nurfaikah78@gmail.com
}

\begin{abstract}
:
This study is a conceptual review of governance management in the perspective of Islamic law. It focuses on the management of a state by reviewing the literature relevant to the system of state governance in Islam. The researcher applied a normative and historical approach using analysis of the concept proposed by Islamic scholars in relation to the system of governance in Islam. The result of the study indicates that the system of government practiced by the Prophet Muhammad and Khulafaurrasidin became a role model in the management of a state. Islamic law has given the concept of state administration professionally and equitably. The Islamic government must be able to provide a concept of religion and at the same time provide the best security and services for its people.
\end{abstract}

Keywords: Governance-Management-Islamic Law.

\begin{abstract}
Abstrak:
Kajian ini merupakan telaah konseptual tentang tata kelola pemerintahan dalam pespektif hukum Islam. Kajian ini memfokuskan pada tata kelola negara dengan mengkaji literatur-literatur yang relevan dengan sistem tata kelola negara dalam Islam. Pendekatan dalam kajian ini yakni pendekatan normatif dan pendekatan historis dengan menggunakan telaah konseptual tentang pemahaman para pemikir Islam dalam kaitannya dengan tata kelola pemerintahan dalam Islam. Hasil kajian menunjukkan bahwa sistem pemerintahan yang dipraktekkam oleh Nabi Muhammad saw. dan Khufaurasidin menjadi panutan dan teladan dalam pengelolaan negara. Hukum Islam telah memberikan konsep tata negara dengan profesional dan berkeadilan. Pemerintah Islam harus mampu memberikan pemahaman agama dan sekaligus memberikan keamanan dan pelayanan yang terbaik untuk rakyatnya.
\end{abstract}

Kata Kunci: Tata Kelola-Pemerintahan-Hukum Islam

\section{Pendahuluan}

Manusia adalah makhluk sosial, tidak dapat hidup sendirian, karena ada sekian banyak kebutuhan yang tidak dapat dipenuhi sendiri, tanpa ada kerja sama atau tanpa bantuan orang lain. ${ }^{1}$ Untuk memperoleh kebutuhan itu harus dengan usaha sungguh-sungguh dengan berpedoman kepada norma-norma agama. Hidup

${ }^{1}$ M. Quraish Shihab, Membumikan Alquran; Fungsi dan Peran Wahyu (Bandung: Mizan, 1992), h. 211 
manusia membutuhkan peraturan demi lancarnya lalu lintas yang akan memberinya petunjuk, seperti kapan harus berhenti, kapan harus bersiap-siap dan kapan harus berjalan. ${ }^{2}$ Agar tidak terjadi benturan dan tabrakan manusia hendaknya selalu menempatkan Kitābullah dan sunnah Rasulnya sebagai referensi utama dalam setiap langkah kehidupan.

Al-Mawdūdi seorang pemikir besar kontemporer menyatakan bahwa Islam adalah suatu agama paripurna yang memuat prinsip-prinsip yang lengkap tentang semua segi kehidupan meliputi moral, etika serta petunjuk di bidang politik, sosial dan ekonomi. ${ }^{3}$ Islam dipahami bukan hanya sebagai suatu keyakinan, tetapi suatu sistem yang lengkap yang mencakup seperangkat jawaban terhadap persoalan yang dialami oleh umat manusia. ${ }^{4}$

Berbeda dengan pandangan sebelumnya, Haikal sebagaimana yang dikemukakan oleh Muhammad Azhar dalam bukunya yang berjudul "Filsafat Politik" bahwa di dalam Alquran dan sunnah tidak terdapat prinsip-prinsip dasar kehidupan yang langsung berhubungan dengen tata pemerintahanan. Kata Haikal, sungguhpun tidak ditemukan sistem pemerintahan dalam Islam, tetapi Islam telah menetapkan prinsip-prinsip dasar peradaban manusia.

Lebih lanjut, Mushthāfa Kemal al-Tatūrk juga memiliki pemikiran tersendiri mengenai agama dan pemerintahan. Menurutnya, agama dan pemerintahan memiliki korelasi, namun dalam pengelolaan urusan agama dan pemerintahan harus terpisah. Karena itu, telah menjadikan pemerintahan Turki sebagai pemerintahan sekuler yang memisahkan urusan dunia dengan urusan agama. ${ }^{5}$

Pemikiran Islam tentang pemerintahan, termasuk di Indonesia yang sampai saat ini masih saja tetap menjadi aktual dalam wacana pemikiran Islam. Oleh karena itu, dapat dirumuskan bahwa pemikiran tentang pemerintahan akan

\footnotetext{
${ }^{2}$ M. Quraish Shihab, Membumikan Alquran; Fungsi dan Peran Wahyu, h. 211.

${ }^{3}$ The Oxford Encyclopedia of The Modern Islamic World (New York : Oxford University Press, 1995), h. 79

${ }^{4}$ Muhammad Azhar, Filsafat Politik Perbadingan antara Islam dan Barat (Jakarta: PT. RajaGrafindo Persada, 1996), h. 135

${ }^{5}$ Harun Nasution, Pembaharuan Dalam Islam; Sejarah Pemikiran dan Gerakan (Cet.X; Jakarta: Bulan Bintang, 1994), h. 142-154
} 
dikaji lebih lanjut secara mendalam mengenai sistem pemerintahan dalam hukum Islam dan tata kelola pemerintahan dalam hukum Islam.

\section{Metodologi}

Kajian ini adalah telaah konseptual tentang tata kelola pemerintahan dalam hukum Islam. Objek kajiannya terfokus pada buku-buku yang terkait dengan pendapat-pendapat ulama dalam menawarkan konsep pengelolaan tata pemerintahan dalam Islam. Selain itu, kajian ini melakukan pendekatan nomatif, untuk melihat kandungan-kandungan nash dalam memberikan konsep tata kelola pemerintahan. Kemudian pendekatan historis dilakukan untuk menggali informasi tata kelola pemerintahan yang dilakoni Nabi, sahabat dan para pejuang-pejuang pembela Islam dalam melakukan tata kelola pemerintahan.

\section{Pembahasan}

\section{Sistem Pemerintahan dalam Islam}

(a) Sistem Pemerintahan

Secara etimologi, pemerintahan berasal dari kata dasar "pemerintah" berarti melakukan pekerjaan menyeluruh. Penambahan awalan "pe" menjadi "pemerintah" berarti badan yang melakukan kekuasaan memerintah. Penambahan akhiran "an" menjadi "pemerintahan" berarti perbuatan, cara, hal atau urusan daripada badan yang memerintah tersebut. ${ }^{6}$

Pemerintahan memang tidak identik dengan negara, karena negara bersifat statis, sedangkan pemerintahan bersifat dinamis. Namun antara negara dengan pemerintahan tidak dapat dipisah karena pemerintahlah yang berfungsi melaksanakan urusan-urusan kenegaraan. Suatu pemerintahan menentukan corak sistem yang dianut oleh negara, apakah teokrasi, nomokrasi dan sebagainya. Corak pemerintahan melahirkan bentuk sebuah negara. Bentuk negara menjadi penting bila pemerintah suatu negara menjadi mesin kekuasaan yang dijalankan oleh seorang pemimpin.

${ }^{6}$ Sirajuddin, Politik Ketatanegaraan Islam Studi Pemikiran A. Hasjmy (Yogyakarta: Pustaka Pelajar, 2007), h. 114. 
Literatur kenegaraan Islam dikenal dengan istilah Imamah, khilafah dan Imarat. Sehubungan dengan hal ini Abd Muin Salim mengatakan:

"Pemerintahan sebagai salah satu struktur dasar sistem politik merupakan lembaga yang menyelenggarakan mekanisme politik atau roda pemerintahan yang dipimpin oleh seorang pejabat yang disebut "wali" atau "amir" atau dengan istilah lainnya yang dikenal dalam perpustakaan politik dan ketatanegaraan Islam."7

Pentingnya eksistensi suatu sistem pemerintahan dianggap sama dengan wajibnya eksistensi negara itu sendiri. A. Hasjmy dengan mengutip pendapat Abdul Kadir 'Audah mengatakan bahwa: "Allah swt. telah mewajibkan agar berhakim kepada ajaran yang telah diturunkan kepada Rasulnya dan memerintah dengannya. Maka menjadi kewajiban kaum muslimin untuk mendirikan suatu pemerintahan yang akan menegakkan perintah-perintah Allah swt. di tengahtengah mereka. Tiap pribadi beribadat dengan menjalankan hukum, sesuai dengan ajaran Allah swt., sebagaimana mereka telah beribadah dengan puasa dan salat. Atas dasar ini, apabila mendirikan negara berdasarkan syariat Islam hukumnya wajib, maka wajib pula hukumnya mendirikan pemerintahan Islam.

Fungsi pemerintahan Islam, yaitu menegakkan perintah Allah swt. Menegakkan Islam, Alquran telah menugaskan kepada pemerintahan Islam supaya memusnahkan syirik dan menguatkan Islam. Mendirikan salat dan mengambil zakat, menyuruh ma'ruf dan melarang yang munkar, mengurus kepentingan-kepentingan manusia dalam batas hukum-hukum Allah swt. ${ }^{8}$

Menurut A. Hasjmy, ada tiga dasar untuk menyelenggarakan pemerintahan, yaitu: keadilan pemerintah, ketaatan rakyat, musyawarah antara pemerintah dengan rakyat. Pemerintahan dalam arti luas berarti seluruh fungsi negara, seperti legislatif, eksekutif, dan yudikatif. Sedangkan pemerintahan dalam arti sempit meliputi fungsi eksekutif saja. ${ }^{9}$ Adapun kata "Islam" bahwa biasanya kata Islam diterjemahkan dengan "penyerahan diri”, penyerahan diri kepada

${ }^{7}$ Abdul Muin Salim, Fiqh Siyasah Konsepsi Kekuasaan Politik dalam Alquran (Jakarta: Raja Grafindo Persada, 2002), h. 294.

${ }^{8}$ A. Hasjmy, Di Mana Letaknya Negara Islam (Surabaya: Bina Ilmu, 1984), h. 83-84.

${ }^{9}$ Sri Soemantri, Sistem-sistem Pemerintahan Negara-Negara Asean (Bandung: Tarsito, 1976), h. 18-19. 
Tuhan atau bahkan kepasrahan. ${ }^{10}$ Secara terminologi sebagaimana dirumuskan oleh Maulana Muhammad Ali, Islam mengandung arti dua macam, yakni (1) mengucap kalimah syahadat; (2) berserah diri sepenuhnya kepada kehendak Allah swt. ${ }^{11}$

Adapun mengenai sistem, bahwa dalam Kamus Umum Bahasa Indonesia, W.J.S. Poerwadarminta, mengartikan sistem sebagai sekelompok bagian-bagian (alat dan sebagainya) yang bekerja bersama-sama untuk melakukan sesuatu maksud. ${ }^{12}$ Sementara menurut Acmad Sanusi, sistem adalah suatu keutuhan kaidah-kaidah yang teratur dan mempunyai tujuan tertentu, sedang dengan kata pemerintahan dimaksudkan suatu lapangan kerja, suatu tugas, khususnya yang disebut Pemerintah dan dalam hubungannya dengan badan perundang-undangan. Setelah oleh Achmad Sanusi diberikan pengertian tentang sistem dan pemerintahan, kemudian dikemukakan sistem-sistem pemerintahan negara yaitu pertama: sistem yang dipusatkan secara mutlak dan bersifat revolusioner. Kedua: sistem presidensil. Ketiga: sistem parlementer.

Menurut Moh. Kusnardi dan Harmaili Ibrahim, pada garis besarnya sistem pemerintahan yang dilakukan pada negara-negara demokrasi menganut sistem parlementer atau sistem presidensil. Tentu saja di antara kedua sistem ini masih terdapat beberapa bentuk lainnya sebagai variasi, disebabkan situasi dan kondisi yang berbeda yang melahirkan bentuk-bentuk semu (quasi), karena jika dilihat dari salah satu sistem di atas, dia bukan merupakan bentuk yang sebenarnya, misalnya quasi parlementer atau quasi presidensil.

Dengan demikian sistem pemerintahan dipahami sebagai suatu sistem hubungan tata kerja antar lembaga-lembaga negara. Sistem pemerintahan merupakan hubungan antara eksekutif dan legislatif.

\footnotetext{
${ }^{10}$ Mohammad Arkoun, Rethinking Islam, Terj. Yudian W.Asmin, Lathiful Khuluq (Yogyakarta: LPMI bekerjasama dengan Pustaka Pelajar, 1996), h. 17.

${ }^{11}$ Maulana Muhammad Ali, Islamologi, (Dinul Islam) (Jakarta: PT Ichtiar Baru Van Hoeve, 1976), h. 2.

${ }^{12}$ W.J.S.Poerwadarminta, Kamus Umum Bahasa Indonesia (Cet. V; Jakarta: PN Balai Pustaka, 1976), h. 95.
} 
(b) Sistem Pemerintahan dalam Islam

Hasan al-Banna mengemukakan bahwa pemerintahan Islam merupakan pemerintahan yang terdiri dari pejabat yang beragama Islam dengan tetap melaksanakan kewajiban dan hukum-hukum agama Islam dan menjauhi kemaksiatan yang dilaramg oleh agama. ${ }^{13}$ Sistem pemerintahan yang pernah dipraktikkan dalam Islam sangat terkait dengan kondisi konstektual yang dialami oleh masing-masing-umat. Dalam rentang waktu yang sangat panjang sejak abad ke-7 Masehi hingga sekarang, umat Islam pernah mempraktekkan beberapa sistem pemerintahan yang meliputi sistem pemerintahan khilafah (khilafah berdasarkan syura dan khilafah monarki), imamah, monarki dan demokrasi.

Khilafah Islam meliputi suku dan bangsa yang maknanya pemerintahan Islam yang dibatasi oleh teritorial. Kesatuan dalam kekhalifahan menjadikan Islam sebagai agama yang mempersatukan. Kedudukan kepala negara dalam konsep khalifah merupakan wakil Nabi saw. dalam menjalankan pemerintahan. Pendapat populer yang dikemukakan oleh Ibn Khaldun menjelaskan bahwa khilafah merupakan kepemimpinan Islam bagi kaum muslimin yang mempunyai tanggungjawab dalam memikul dakwah kemajuan dan perkambangan Islam. Menegakkan khilafah adalah kewajiban bagi semua kaum muslimin di seluruh penjuru dunia. Menjalankan kewajiban yang demikian itu, sama dengan menjalankan kewajiban yang diwajibkan Allah swt. atas semua kaum muslimin. Siksaan pedih diberikan ganjaran bagi melalaikan pelaksanaan kekhalifahan. ${ }^{14}$

Berdasarkan ijma' sahabat, wajib hukumnya mendirikan kekhalifahan. Setelah Rasulullah wafat, mereka bersepakat untuk mendirikan kekhalifahan bagi Abu Bakar, kemudian Umar, Usman, dan Ali, sesudah masing-masing dari ketiganya wafat. Para sahabat telah bersepakat sepanjang hidup mereka atas kewajiban mendirikan kekhalifahan, meski mereka berbeda pendapat tentang orang yang akan dipilih sebagai khalifah, tetap mereka tidak berbeda pendapat

\footnotetext{
${ }^{13}$ Muhammad Abdul Qadir Abu Faris, Fiqih Politik Hasan al-Banna (Terj. Odie al-Faeda, Solo: Media Insani, 2003), h. 39.

${ }^{14}$ Mujar Ibnu Syarif dan Khamami Zada, Fiqh Siyasah Doktrin dan Pemikiran Politik Islam (Jakarta: Erlangga, 2008), h. 204-205.
} 
secara mutlak mengenai berdirinya kekhalifahan. Dipandang dalam aspek agama bahwa khalifah merupakan penegakan agama di dunia ini.

Jabatan ini merupakan pengganti Nabi saw. dengan tugas yang sama, yakni mempertahankan agama dan menjalankan kepemimpinan dunia. Lembaga ini disebut khilafah (kekhalifahan). Orang yang menjalankan tugas itu disebut khalifah. Penamaan khalifah Allah swt. masih sering muncul pertentangan. Ketegasannya dijelaskan bahwa manusia diciptakan sebagai khalifah di muka bumi ini. Jumhur ulama melarang memberi nama demikian, karena menurut mereka ayat tersebut tidak bermaksud begitu. Lagi pula, Abu Bakar menolak ketika beliau dipanggil dengan nama tersebut. "Saya bukan khalifah Allah swt. tapi khalifah Rasulullah". ${ }^{15}$

Hubungannya dengan sub judul ini, maka pemerintahan yang dimaksud yaitu pemerintahan dalam perspektif Islam yang tentunya pembahasan dengan menengok pemerintahan di masa Nabi saw. (negara Madinah). Sehubungan dengan itu, menurut Mohammed S. Elwa bahwa siapa saja terlibat dalam sebuah riset tentang prinsip-prinsip sistem politik Islam dan sejarahnya, maka harus menerima kenyataan bahwa Rasulullah saw. adalah yang pertama kali membentuk pemerintahan Islam, sesudah hijrah dari Mekkah ke Madinah. ${ }^{16}$

Menurut Hasan al-Banna, Islam menganggap pemerintahan sebagai salah satu dasar sistem sosial yang dibuat untuk manusia. Islam tidak menghendaki kekacauan atau anarkis dan tidak membiarkan satu jamaah tanpa Imam (pemimpin). Jadi orang yang menganggap bahwa Islam tidak memberi penjelasan tentang politik atau politik bukan bidang pembahasannya, maka mengkhianati dirinya dan juga mengkhianati Islam. ${ }^{17}$

Sebagaimana diketahui bahwa masa kenabian adalah masa yang pertama dari sejarah Islam, dan semenjak Rasulullah saw. memulai dakwahnya sampai beliau wafat yang dinamakan masa itu dengan masa kenabiaan atau masa wahyu.

\footnotetext{
${ }^{15}$ Mujar Ibnu Syarif dan Khamami Zada, Fiqh Siyasah Doktrin dan Pemikiran Politik Islam, h. 206.

${ }^{16}$ Mohammed S. Elwa, Sistem Politik dalam Pemerintahan Islam (Terj. Anshori Thayib, Surabaya: PT Bina Ilmu, 1983), h. 19.

${ }^{17}$ Hasan al-Banna, Majmu'ah Rasa'il al-Imam Syahid Hasan al-Banna, alih bahasa, Su'adi Sa'ad, "Konsep Pembaruan Masyarakat Islam" (Jakarta: Media Da'wah, 1986), h. 374-375.
} 
Masa demikian dikenal dengan masa kejayaan dalam keagungan agama Islam. Masa kenabiaan itu, terbagi kepada dua periode yang dipisahkan oleh hijrah. Dalam pada itu tidak ada di antara kedua fase itu perbedaan yang tegas bahkan periode yang pertama, adalah sebagai perintis jalan bagi yang kedua.

Di periode yang pertama, timbullah benih masyarakat Islam dan dalam periode inilah ditetapkan dasar-dasar Islam yang pokok. Dalam periode yang kedua, disempurnakan pembentukan masyarakat Islam serta dijelaskan sesuatu yang tadinya dikemukakan secara ringkas (global) dan disempurnakan perundangundangan dan tata aturan dengan melahirkan prinsip-prinsip baru, serta menerapkan prinsip-prinsip itu ke dalam kenyataan. Dalam periode inilah nampak masyarakat Islam dalam bentuk kemasyarakatan sebagai satu kesatuan yang bergerak menuju kepada satu tujuan. ${ }^{18}$

Tinjauan politik, sejarah lebih memperhatikan periode yang kedua, karena jamaah Islamiyah pada waktu itu telah memperoleh kedaulatannya yang sempurna dan kemerdekaan yang penuh serta prinsip-prinsipnya mulai diterapkan ke dalam alam kenyataan. Dalam pada itu, kedua-dua periode ini dapat dikatakan dalam tinjauan sejarah, adalah masa pembentukan dasar dan membangun. Maka dia mempunyai kedudukan yang sangat tinggi nilainya. Karena dialah yang memberi jiwa kepada masa-masa yang datang sesudahnya. Dari segi tafkir nazhary, maka masa ini membentuk daya gerak yang menghasilkan teladan-teladan yang sempurna yang menjadi tumpuan pikiran para ahli, dan membentuk pula titik perjumpaan bermacam aliran. Walaupun satu sama lainnya menempuh jalan sendiri-sendiri. ${ }^{19}$

Terbentuknya Negara Madinah, akibat dari perkembangan penganut Islam yang menjelma menjadi kelompok sosial dan memiliki kekuatan politik riil pada pasca periode Mekkah di bawah pimpinan Nabi Saw. Pada periode Mekkah pengikut beliau yang jumlahnya relatif kecil belum menjadi suatu komunitas yang mempunyai daerah kekuasaan dan berdaulat. Mereka merupakan golongan minoritas yang lemah dan tertindas, sehingga tidak mampu tampil menjadi

\footnotetext{
${ }^{18}$ Hasbi Ash-Shiddieqy, Islam \& Politik Bernegara (Semarang: PT. Pustaka Rizki Putra, 2002), h. 3 .

${ }^{19}$ Hasbi Ash-Shiddieqy, Islam \& Politik Bernegara, h. 3.
} 
kelompok sosial penekan terhadap kelompok sosial mayoritas kota itu yang berada di bawah kekuasaan aristokrat Quraisy, yang masyarakatnya homogen. Posisi Nabi Saw. dan para umat di Madina menpunyai kedudukan fundamental yang mampu berdiri sendiri. Nabi saw. sendiri menjadi kepala dalam masyarakat yang baru dibentuk itu dan yang akhirnya merupakan suatu negara. Suatu negara yang daerah kekuasaannya di akhir zaman Nabi saw. meliputi seluruh Semenanjung Arabia. Dengan kata lain di Madinah, Nabi Muhammad bukan lagi hanya mempunyai sifat Rasul, tetapi juga mempunyai sifat kepala negara. ${ }^{20}$

Praktek pemerintahan yang dilakukan Muhammad saw. sebagai kepala negara tampak pada pelaksanaan tugas-tugas yang tidak terpusat pada diri beliau. Piagam Madinah beliau diakui sebagai pemimpin tertinggi, yang berarti pemegang kekuasaan legislatif, eksekutif dan yudikatif. Tapi walaupun pada masa itu orang belum mengenal teori pemisahan atau pembagian kekuasaan, namun dalam prakteknya beliau mendelegasikan tugas-tugas eksekutif dan yudikatif kepada para sahabat yang dianggap cakap dan mampu.

Timbulnya berbagai masalah yang dihadapi dan perkembangan wilayah kekuasaan menuntut adanya peta pembagian tugas. Pemerintahan di Madinah, Nabi saw. menunjuk beberapa sahabat sebagai pembantu beliau, sebagai katib (sekretaris), sebagai 'amil (pengelola zakat) dan sebagai qadhi (hakim). Untuk pemerintahan di daerah, Nabi saw. mengangkat seorang wali, seorang qadhi dan seorang 'amil untuk setiap daerah atau propinsi. Pada masa Rasulullah saw. negara Madinah terdiri dari sejumlah propinsi, yaitu Madinah, Tayma, al-Janad, daerah Banu Kindah, Mekkah, Najran, Yaman, Hadramaut, Oman dan Bahrain. Masingmasing pejabat memiliki kewenangan sendiri dalam melaksanakan tugasnya. Seorang qadhi diberi beberapa kebebasan penuh dalam memutuskan setiap perkara, karena secara struktural ia tidak berada di bawah wali. Ali bin Abi Thalib dan Muaz bin Jabal adalah dua orang qadhi yang diangkat Nabi Saw., yang bertugas di dua propinsi berbeda.

${ }^{20}$ J. Suyuthi Pulungan, Fiqh Siyasah, Ajaran Sejarah dan Pemikiran (Jakarta: PT Raja Grafindo Persada, 2002), h. 97. 
Nabi saw. juga selalu menunjuk sahabat untuk bertugas di Madinah bila beliau bertugas keluar, memimpin pasukan misalnya. Demikian pula kedudukan beliau sebagai panglima perang, beliau sering wakilkan kepada para sahabat. Seperti dalam perang Mu'tah $(8 \mathrm{H})$, beliau menunjuk Zaid bin Haritsah sebagai panglimanya. Beliau juga berpesan: Kalau Ziad gugur, maka Ja'far bin Abi Thalib memegang pimpinan, dan kalau Ja'far gugur, maka Abdullah bin Rawaha memegang pimpinan. ${ }^{21}$

Pranata sosial di bidang ekonomi yang juga menjadi bagian dari tugas kenegaraan, adalah usaha Nabi Muhammad dalam mewujudkan keadilan dan kesejahteraan sosial rakyat Madinah. Tujuan ini beliau mengelola zakat, infaq dan sadaqah yang berasal dari kaum muslimin, ghanimah yaitu harta rampasan perang dan jizyah (pajak) yang berasal dari warga negara non-muslim. Jizyah oleh kalangan juris muslim disebut juga "pajak perlindungan" (protection tax).

Praktek pemerintahan yang dilakukan oleh Muhammad saw. tersebut, tampak bahwa beliau dalam kapasitasnya sebagai kepala negara dalam memerintah negara Madinah dapat dikatakan amat demokratis. Sekalipun undangundangnya berdasarkan wahyu Allah swt. yang beliau terima, dan Sunnah beliau termasuk Piagam Madinah. Nabi mencerminkan dirinya sebagai Rasul Allah swt. yang wajib di taati, namun dalam melaksanakan persoalan Nabi saw. tidak pernah otoriter dalam bertindak.

Beberapa ahli mengemukakan pendapat yang berbeda mengenai bentuk dan corak Negara Madinah tersebut di zaman Rasulullah. Ali Abd al-Raziq berpendapat bahwa Nabi tidak mempunyai pemerintahan dan tidak pula membentuk kerajaan. Sebab beliau hanya seorang Rasul sebagaimana RasulRasul lain, dan bukan sebagai seorang raja atau pembentuk negara. Pembentukan pemerintahan tidak termasuk dalam tugas yang diwahyukan kepada beliau. Walaupun kegiatan-kegiatan tersebut dapat disebut kegiatan pemerintahan, namun bentuk pemerintahannya sangat sederhana, dan kekuasaannya bersifat umum, mencakup soal dunia dan akhirat. Karena sebagai Rasul beliau harus mempunyai

\footnotetext{
${ }^{21}$ Muhammad Husain Haekal, Sejarah Hidup Muhammad (Terj. Ali Audah, Cet. 29; Jakarta: Litera Antar Nusa, 2003), h. 399-440.
} 
kekuasaan yang lebih luas dari kekuasaan seorang raja terhadap rakyatnya. Kepemimpinan beliau adalah kepemimpinan seorang Rasul yang membawa ajaran baru, dan bukan kepemimpinan seorang raja, dan kekuasaannya hanyalah kekuasaan seorang Rasul, bukan kekuasaan seorang raja. ${ }^{22}$ Berbeda dari pendapat ini, Khuda Baks, penulis dari Gerakan Aligarh India, menyatakan bahwa Nabi saw. tidak hanya membawa agama baru, tetapi juga membentuk suatu pemerintahan yang bercorak teokratis yang puncaknya berdiri seorang wakil Tuhan di muka bumi.

Pada umumnya, para ahli berpendapat, masyarakat yang dibentuk oleh Nabi di Madinah itu adalah negara, dan beliau sebagai kepala negaranya. Watt, seorang orientalis, menyatakan masyarakat yang dibentuk oleh Nabi di Madinah bukan hanya masyarakat agama, tetapi juga masyarakat politik sebagai pengejawantahan dari persekutuan suku-suku bangsa Arab. Instansi persekutuan itu adalah rakyat Madinah dan Nabi Muhammad sebagai pemimpinnya. Sebab beliau disamping seorang Rasul juga adalah kepala negara. Hitti juga berpendapat, terbentuknya masyarakat keagamaan di Madinah yang bukan berdasarkan ikatan darah membawa kepada terbentuknya negara Madinah. Di atas puncak negara ini berdiri Tuhan, dan Nabi Muhammad adalah wakil Tuhan di muka bumi. Beliau disamping tugas kerasulannya juga memiliki kekuasaan dunia seperti kepala negara biasa. Dari Madinah teokrasi Islam tersebar ke seluruh Arabia dan kemudian meliputi sebagian terbesar dari Asia Barat sampai Afrika Utara.

Negara Madinah itu memang ada dua kedaulatan, yaitu kedaulatan Syariat Islam sebagai Undang-Undang negara itu, dan kedaulatan umat. Syariat Islam sebagai undang-undang di satu segi ia membatasi kekuasaan umat untuk membuat undang-undang mengenai hukum sesuatu bila penjelasan hukumnya sudah jelas dalam nash Syariat. Tapi di segi lain, memberi hak kebebasan kepada umat untuk menetapkan hukum suatu hal yang belum jelas hukumnya, memerintahkan kepada umat agar memusyawarahkan setiap urusan mereka, yaitu urusan yang belum jelas hukumnya dalam nash syariat. Ini telah dicontohkan oleh Nabi Muhammad

\footnotetext{
${ }^{22}$ Karen Armstrong, Muhammad Biografi Sang Nabi Saw. (Terj. Joko Sudaryanto, Yogyakarta: Penerbit Jendela, 2004), h. 250-280.
} 
sebagai salah satu aktivitasnya yang menonjol di bidang pranata sosial politik dalam memimpin negara Madinah. Jadi negara Madinah itu adalah negara yang berdasarkan syariat Islam, tapi ia memberi hak bermusyawarah dan berijtihad kepada umat. Dengan demikian corak negara Madinah adalah negara berasaskan syariat Islam, dan bersifat demokratis.

Berdasarkan paparan di atas, dapatlah ditegaskan bahwa praktek pemerintahan yang dilakukan Muhammad saw. sebagai kepala negara tampak pada pelaksanaan tugas-tugas yang tidak terpusat pada diri beliau. Piagam Madinah beliau diakui sebagai pemimpin tertinggi, yang berarti pemegang kekuasaan legislatif, eksekutif dan yudikatif. Tapi walaupun pada masa itu orang belum mengenal teori pemisahan atau pembagian kekuasaan, namun dalam prakteknya beliau mendelegasikan tugas-tugas eksekutif dan yudikatif kepada para sahabat yang dianggap cakap dan mampu.

\section{Tata Kelola Pemerintahan dalam Perspektif Hukum Islam}

Menurut Hasan al-Banna sebagaimana dikutip oleh Muhammad Abdul Qadir Abu Faris, kewajiban atau tugas-tugas pemerintah Islam adalah pertama, menjaga keamanan dan melaksanakan undang-undang; kedua, menyelenggarakan pendidikan; ketiga, mempersiapkan kekuatan; keempat, memelihara kesehatan; kelima, memelihara kepentingan umum; keenam, mengembangkan kekayaan dan memelihara harta benda; ketujuh, mengokohkan akhlak; kedelapan, menyebarkan dakwah. ${ }^{23}$ Adapun tujuan pendirian negara dan pemerintahan tidak terlepas dari tujuan yang hendak dicapai oleh umat Islam, yaitu memperoleh kebahagiaan di dunia dan keselamatan di akhirat. Karena tujuan ini tidak mungkin dicapai hanya secara pribadi-pribadi, maka Islam menekankan pentingnya pendirian negara dan pemerintahan sebagai sarana untuk memperoleh tujuan tersebut. ${ }^{24}$

Mendirikan khilafah atau pemerintahan dalam pandangan para juris sunni wajib menurut hukum agama sebagai pengganti tugas Nabi Saw. mengatur kehidupan dan urusan umat baik keduniaan, keagamaan dan untuk memelihara

\footnotetext{
${ }^{23}$ Muhammad Abdul Qadir Abu Faris, Fiqih Politik, h. 40.

${ }^{24}$ Muhammad Iqbal, Fiqh Siyasah Kontektualisasi Doktrin Politik Islam (Jakarta: Gaya Media, Pratama, 2007), h. 134.
} 
agama. Umat wajib menunjukkan kepatuhan dan ketaatan kepadanya. Kekuasaan politik harus dijadikan sebagai alat untuk melaksanakan syariat Islam, menegakkan keadilan dan mewujudkan kesejahteraan rakyat, memelihara persamaan umat lewat kerjasama dan tolong-menolong, serta menciptakan keamanan dan ketenangan. ${ }^{25}$

Menurut Imam al-Mawardi tugas-tugas yang harus diemban oleh kepala negara (sebagai kepala pemerintahan) ada sepuluh hal sebagai berikut:

1. Menjaga agama agar tetap berada di atas pokok-pokoknya yang konstan (tetap) dan sesuai pemahaman yang disepakati oleh generasi salaf (terdahulu) umat Islam. Jika muncul pembuat bid'ah atau pembuat kesesatan, berkewajiban untuk menjelaskan hujjah (alasan) kebenaran baginya dan menjelaskan pemahaman yang benar kepadanya. Serta menuntutnya sesuai dengan hak-hak dan aturan hukum yang ada, sehingga agama terjaga dari kerancuan dan pemahaman yang salah;

2. Menjalankan hukum bagi pihak-pihak yang bertikai dan memutuskan permusuhan antar pihak yang berselisih, sehingga keadilan dapat dirasakan oleh semua orang. Tidak ada orang zalim yang berani berbuat aniaya dan tidak ada orang yang dizalimi yang tidak mampu membela dirinya;

3. Terciptanya keamanan dalam masyarakat, sehingga masyarakat bebas dari rasa was-was untuk bepergian;

4. Menjalankan hukum had sehingga larangan-larangan Allah swt. tidak ada yang melanggarnya dan menjaga hak-hak hambanya agar tidak hilang binasa.

5. Menjaga perbatasan negara dengan perangkat yang memadai dan kekuatan yang dapat mempertahankan negara sehingga musuh-musuh negara tidak dapat menyerang negara Islam dan tidak menembus pertahanannya serta tidak dapat mencelakakan kaum muslimin atau kalangan kafir mu'ahad (yang diikat janjinya).

6. Berjihad melawan pihak yang menentang Islam setelah disampaikan dakwah kepadanya hingga ia masuk Islam atau masuk dalam jaminan Islam atau

\footnotetext{
${ }^{25}$ Suyuthi Pulungan, Fiqh Siyasah, h. 259
} 
dzimmah. Dengan demikian, usaha untuk menjunjung tinggi agama Allah swt. di atas agama-agama seluruhnya dapat diwujudkan.

7. Menarik fai-i (hasil rampasan) dan memungut zakat sesuai dengan ketentuan yang telah ditetapkan oleh syarieat Islam secara jelas dalam nash dan ijtihad. ${ }^{26}$

8. Mengatur penggunaan harta baitul-maal secara efektif, tanpa berlebihan atau kekurangan, dan memberikannya pada waktunya, tidak lebih dahulu dari waktunya dan tidak pula menundanya hingga lewat dari waktunya.

9. Mengangkat pejabat-pejabat yang terpercaya dan mengangkat orang-orang yang kompeten untuk membantunya dalam menunaikan amanah dan wewenang yang ia pegang dan mengatur harta yang berada di bawah wewenangnya, sehingga tugas-tugas dapat dikerjakan dengan sempurna dan harta negara terjaga dalam pengaturan orang-orang yang tepercaya.

10. Agar ia melakukan sendiri inspeksi atas pekerjaan para pembantunya dan meneliti jalannya proyek sehingga ia dapat melakukan kebijakan politik umat Islam dengan baik dan menjaga negara. la tidak boleh menyerahkan tugas ini kepada orang lain karena sibuk menikmati kelezatan atau beribadah, karena orang yang terpercaya dapat saja menjadi pengkhianat dan orang yang baik dapat saja berubah menjadi penipu, Allah swt. berfirman dalam QS. AlShaad/38:26:

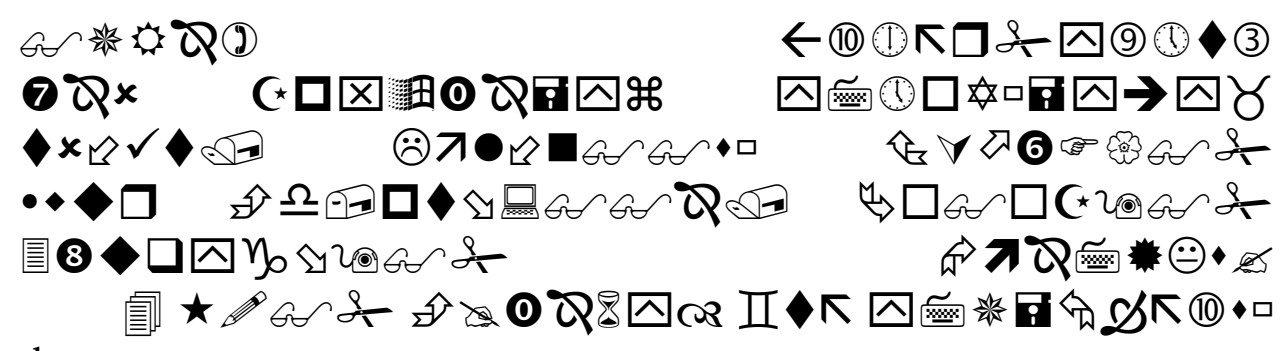

Terjemahnya:

Hai Dawud, sesungguhnya Kami menjadikan kamu khalifah (penguasa) di muka bumi, maka berilah keputusan (perkara) di antara manusia dengan

${ }^{26}$ Nicolas P. Aghnides, The Background Introduction To Muhammedan Law, New York: Published by The Ab. "Sitti Sjamsijah" Publishing Coy Solo (Java, With The Authority-License of Columbia University Press, t.t), h. 95. 
adil dan janganlah kamu mengikuti hawa nafsu karena akan menyesatkan kamu cari jalan Allah swt. ${ }^{27}$

Tugas dan tujuan lembaga pemerintahan dalam pandangan al-Ghazali, adalah lembaga yang memiliki kekuasaan dan menjadi alat melaksanakan syariat, mewujudkan kemaslahatan rakyat, menjamin-ketertiban urusan dunia dan urusan agama. Lembaga pemerintahan juga berfungsi sebagai lambang kesatuan umat Islam demi kelangsungan sejarah umat Islam. ${ }^{28}$

Sejalan dengan persyaratan kepala pemerintahan, tugas dan tujuan utama pemerintahan dalam pandangan Ibn Taimiyah untuk melaksanakan syari'at Islam demi terwujudnya kesejahteraan umat, lahir dan batin, serta tegaknya keadilan dan amanah dalam masyarakat. Paradigma pemikirannya ini banyak disandarkan kepada ayat-ayat Alquran dan hadis. Tidak berbeda dari pendahulunya, Ibn Khaldun menyatakan sesungguhnya kehidupan di dunia ini bukanlah tujuan akhir dari keberadaan manusia. Kehidupan manusia di dunia ini adalah satu marhalah yang dijalani menuju kehidupan lain, yaitu kehidupan akhirat. Undang-undang Islam yang bersifat politik menaruh perhatian terhadap kehidupan dunia, maka imamah, warisan yang ditinggalkan oleh Nabi Muhammad saw. adalah untuk melaksanakan hukum-hukum Allah swt. demi terwujudnya kemaslahatan manusia di dunia dan akhirat.

\section{Penutup}

Berdasarkan berbagai uraian di atas, maka dapat disimpulkan:

1. Sistem pemerintahan dalam hukum Islam diselaraskan dengan pemerintahan Nabi saw. dalam mengelolah Madinah menjadi daerah maju dalam berbagai aspek, bahkan menjadi pusat ekonomi. Sistem pemerintahan dengan demokratis dengan mengedepankan musyawarah untuk mufakat. Selain itu, pemerintahan khulafaurasidin yang membentuk lembaga-lembaga dalam pengelolaan negara yang baik.

2. Tata kelola pemerintahan dalam hukum Islam menghendaki pemerintahan yang bersih dan lembaga-lembaga pemerintahan menjalankan tugas dan

${ }^{27}$ Yayasan Penterjemah/Pentafsir Alquran, Alquran dan Terjemahnya (Surabaya: Depag RI, 2005), h. 736.

${ }^{28}$ Suyuthi Pulungan, Fiqh Siyasah, h. 260-261. 
tanggungjwabnya dengan profesioanl. Tugas dan tujuan utama pemerintahan adalah untuk melaksanakan syari'at Islam demi terwujudnya kesejahteraan umat, lahir dan batin, serta tegaknya keadilan dan amanah dalam masyarakat.

\section{Daftar Pustaka}

Alquran dan Terjemahnya

Azhar, Muhammad. Filsafat Politik Perbadingan antara Islam dan Barat. Jakarta: PT. RajaGrafindo Persada, 1996.

Ash-Shiddieqy, Hasbi. Islam \& Politik Bernegara. Semarang: PT. Pustaka Rizki Putra, 2002.

al-Banna, Hasan. Majmu'ah Rasa'il al-Imam Syahid Hasan al-Banna, alih bahasa, Su'adi Sa'ad, "Konsep Pembaruan Masyarakat Islam". Jakarta: Media Da'wah, 1986.

Elwa, Mohammed S. Sistem Politik dalam Pemerintahan Islam. Terj. Anshori Thayib, Surabaya: PT Bina Ilmu, 1983.

Faris, Muhammad Abdul Qadir Abu. Fiqih Politik Hasan al-Banna. Terj. Odie alFaeda, Solo: Media Insani, 2003.

Hasjmy, A. Di Mana Letaknya Negara Islam. Surabaya: Bina Ilmu, 1984.

Haekal, Muhammad Husain. Sejarah Hidup Muhammad. Terj. Ali Audah, Cet. 29; Jakarta: Litera Antar Nusa, 2003.

Iqbal, Muhammad. Fiqh Siyasah Kontektualisasi Doktrin Politik Islam. Jakarta: Gaya Media, Pratama, 2007.

Shihab, M. Quraish. Membumikan Al-Qur'an; Fungsi dan Peran Wahyu. Bandung: Mizan, 1992.

The Oxford Encyclopedia of The Modern Islamic World. New York : Oxford University Press, 1995.

Nasution, Harun. Pembaharuan Dalam Islam; Sejarah Pemikiran dan Gerakan. Cet.X; Jakarta: Bulan Bintang, 1994.

Surbakti, Ramlan. Memahami Ilmu Politik. Jakarta: PT Grasindo, 1999.

Salim, Abdul Muin. Figh Siyasah Konsepsi Kekuasaan Politik dalam Al-Qur'an. Jakarta: Raja Grafindo Persada, 2002.

Soemantri, Sri. Sistem-sistem Pemerintahan Negara-Negara Asean. Bandung: Tarsito, 1976.

Syarif, Mujar Ibnu dan Khamami Zada. Fiqh Siyasah Doktrin dan Pemikiran Politik Islam. Jakarta: Erlangga, 2008.

Pulungan, J. Suyuthi. Fiqh Siyasah, Ajaran Sejarah dan Pemikiran. Jakarta: PT Raja Grafindo Persada, 2002. 
Al-BayyinaH: Jurnal Islamic Law

Nur Faikah:

"Tata Kelola Pemerintahan dalam Hukum Islam" 